\title{
Modelling inflation-interest rate nexus for Ghana
}

Samuel Asuamah Yeboah

School of Business and Management Studies, Sunyani Technical University, Ghana nelkonsegal@yahoo.com

Phone: +233244723071

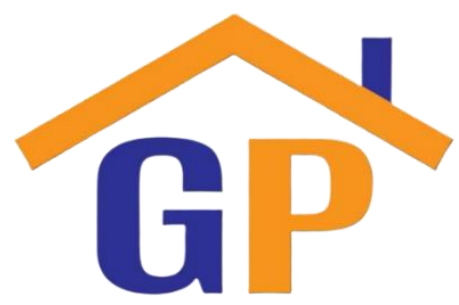

Article History

Received on 8 September 2020

$1^{\text {st }}$ Revision on 16 September 2020

$2^{\text {nd }}$ Revision on 23 September 2020

$3^{\text {rd }}$ Revision on 4 October 2020

$4^{\text {th }}$ Revision 8 October 2020

Accepted on 8 October 2020

\begin{abstract}
Purpose: The research assesses the interest rates-inflation association in the case of Ghana between 2007 and 2013. Monthly and quarterly data were used.
\end{abstract}

Research Methodology: The model of the vector error correction and Johansen were used to investigate the long-term and short-term association in the model estimated respectively. The vector autoregression (VAR) test was used to model the joint dynamics between the variables. GRETL software was used in these tests. Granger predictive test was done with the EViews software.

Results: The findings of the result confirm both long-run and a short-run association in the model and as well as neutral granger predictive causality.

Limitations: Though the Johansen test is more appropriate for multivariate modelling, Engle-Granger test is considered to be more robust in most cases and as such future studies should consider using the two models in a comparative study to assess whether the current conclusions can collaborate.

Contribution: The paper contributes to knowledge in the field of inflation and Interest rates association, in relation to the financial markets. Future Research models that account for structural breaks and panel works are worth doing.

Keywords: Fisher effect, Treasury bill rates long run, Johansen model

How to cite: Yeboah, S. A. (2020). Modelling inflation-interest rate nexus for Ghana. International Journal of Financial, Accounting, and Management, 2(3), 227 -241.

\section{Introduction}

The factors that influence Treasury bill rates (T-bill rates) have gained popularity in the literature for many years since the works of Fisher (1930). The central government as a short-term investment has extensively used T-bills. T-bills mature in different periods such as 1-year, 182-days and 91-days. Among the factors that influence T-bill rates is inflation (the rise in the average price of products). Inflation is expected to positively influence T-bill rates historically. Studies have examined whether inflation and T-bill move together in the long-term. The research findings in the literature have not been consistent. The findings of these studies are reported in various researchers works (See Wilcox, 1983; Benhabib, Schmitt-Grohe \& Uribe, 2002; Berument \& Jelassi, 2002; Fahmy \& Kandil, 2002; Panopoulou, 2005; Gül \& Ekinci, 2006; Herwartz \& Reimers, 2006; Westerlund, 2006; Sathye, Sharma, \& Liu, 2009; Ayub, Rehman, Iqbal, Zaman, \& Atif, 2014; Ida \& Luguterah, 2014).

The current paper is based on the Fisher (1930) theory of interest. According to the theory, the interest rate is a function of inflation and when inflation increase by $1 \%$, it leads to interest rates increasing by about 1\%, using US data. Some previous researchers (Fama, 1975, Fama \& Schwert, 1977) corroborated the findings of Fisher (1930). Other works (Summers, 1983) contradicted Fisher (1930) also using US data. 
The findings of recent empirical studies such as Panopoulou (2005) for 14 OECD countries supported the Fisher (1930) hypothesis using interest rates based on both short-term and long-term rates also support the Fisher preposition. In a similar study for Turkey for the period 1984-2003, Gül and Ekinci (2006) reported the stable short-run and long-run association in modelling inflation and interest rates. Herwartz and Reimers (2006) investigated the link between interest rate and inflation for some 114 countries for a year of 45 and reported a statistical stable link between inflation and interest rate in the long-run.

In the economies of East Asian, Ling et al. (2008) examined the Fisher preposition. The findings of the study supported the Fisher (1930) proposition for the period under discussion. Westerlund (2008) studied the interest rate and inflation nexus for 20 OECD economies for the period 180 to 2004 and reported a long-term association in the two series. The findings provided support for the Fisher (1930) hypothesis. Sathye, Sharma and Liu (2009) investigated the rates of interest and inflation association for India. Their study findings indicated a statistically stable link between inflation and interest rate in the long-run which supports the Fisher hypothesis.

Mahdi and Masood (2011) analysed the link between inflation and interest rate for Iran in testing for the Fisher (1930) hypothesis. Their study findings indicated a stable association between inflation and interest rates in the long-term. The findings supported the Fisher (1930) hypothesis. Ayub et al. (2014) examined the Fisher (1930) for Pakistan for the period 1973-2010. Their research findings indicated a stable association between rates of interest and inflation in the long-term, supporting the Fisher hypothesis. Jaradat and AI-Hhosban (2014) studied the link between rates of interest and inflation for Jordan for the period 1990-2012. Their study findings indicated a stable association between rates of interest and inflation in the long-term. Their findings show a significant positive association between interest rates and inflation.

Logubayom and Luguterah (2014) examined the long-run link between exchange rates, inflation and interest rate (91-day T-bill, the 182-day T-bill) for the period 2000 to 2011 using time series data for Ghana. The findings supported the long run between inflation and interest rates. Logubayom and Luguterah (2014) also reported a significant unidirectional prediction between inflation and interest rates (182-day treasury bill rate) with causality to the rates of interest from inflation without feedback. They, however, reported of the insignificant predictive direction between rates of interest (proxied by 91-day treasury bill rates), and inflation.

The motivation of the present research work is that not many empirical works focusing on the study area are reported in the literature using the various analysis methods the present study has used. The current study extends previous studies by using both 182-day T-bill rates and 91-day T-bill rates to add to the existing literature. The paper objective is to assess the association between rates of interest and inflation to determine whether there is stable long-run nexus and its implication for Fisher (1930) hypothesis existence in Ghana. The paper provides an answer to the researcher question such as what is the nature of the association between interest rates and inflation. The study tests the assumption that Fisher (1930) hypothesis is applicable for the study period.

The use of secondary data comes with various challenges that might affect the results of the study, such as criticism of the estimation (ADF, KPSS, Error correction vector, the Johansen, and the VAR) methods and the secondary data used.

The next sections of the study comprise of the econometric methodology, in section 2; the section for the estimated results, and discussion, in section 3; and conclusion section, in section 4 .

\section{Research methodology}

\subsection{Estimation methodology}

The study modelled interest rates-inflation association based on time series modelling by assessing the dynamic relation between rates of interest and inflation, as well as investigating both the short-run and long-run association between the rates of interest and inflation. Equation (1) shows the empirical model, whereas the theoretical model is based on the Fisher hypothesis explained in the introduction. In the model inflation variable (INF) is the independent variable, whereas interest rates variable is the dependent variable (Proxied by 91-day T-Bill rates, and 182-day T-Bill rates).

$$
T B R_{t}=\alpha_{0}+\beta_{i} I N F_{t}+\varepsilon_{t} \ldots \ldots \ldots \ldots \ldots \ldots \ldots .(1)
$$


Where $\mathrm{INF}=$ is inflation rates; $\mathrm{TBR}=$ interest rates (proxied by $\mathrm{T}$-bill rates); and $\varepsilon_{\mathrm{t}}=$ error term.

The estimation methods for the study is the Johansen method (see Johansen 1995 for a full description of the procedure).) (for the long-run link. The Johansen model is as specified in equation (2), where $x_{t}=\mathrm{Nx} 1$ vector of variables, with one order of integration, order I (1). The Nx1 vector of innovations $=$ error term $\left(\varepsilon_{\mathrm{t}}\right)$.

$$
x_{t}=\mu+A_{t} x_{t-1}+\cdots+A_{p} x_{t-p}+\varepsilon_{t}
$$

The short-run nexus was investigated by employing the vector error correction model (VECM) (for further readings on the error correction procedure see Banerjee, Dolado, Galbraith, \& Hendry, 1993),

where

$\Delta \mathrm{x}_{\mathrm{t}}=\mathrm{x}_{\mathrm{t}}-\mathrm{x}_{\mathrm{t}^{-1}}$; and $\Delta \mathrm{y}_{\mathrm{t}}=\mathrm{y}_{\mathrm{t}}-\mathrm{y}_{\mathrm{t}}$. In the model $\gamma=$ the error correction rate, and it defines the rate of disequilibrium that is corrected in moving to the long run from the short-run. The disequilibrium is given as $\left(\mathrm{x}_{\mathrm{t}-1}-\beta \mathrm{y}_{\mathrm{t}-1}\right)$. Equation (3) shows the error correction model.

$$
\Delta x_{t}=\lambda_{0}+\lambda_{1} \Delta y_{t}-\gamma\left(x_{t-1}-\beta y_{t-1}\right)+\varepsilon_{t}
$$

The effect of inflation on the interest rate (proxied by treasury bill rates) was modelled using the vector autoregression model (VAR) by using series variables as a function that is linear of their past lag values in the model. Because the series are order one integrated, VAR (1) the models are specified as in equation (4) and equation (5).

$$
\begin{aligned}
& \Delta y_{t, 1}=\beta_{1}+\emptyset_{11} x_{t-1,1}+\emptyset_{12} x_{t-1,2}+w_{t, 1} \\
& \Delta y_{t, 2}=\beta_{2}+\emptyset_{21} x_{t-1,1}+\emptyset_{22} x_{t-1,2}+w_{t, 2}
\end{aligned}
$$

The VAR model is further specified as in equation (6) where $\mu_{\mathrm{t}}$ is equal to $(1, \mathrm{t})$ includes terms to simultaneously fit the constant and trend. This allows estimation of the model to be done without detrending the series separately. The method allows the model to be estimated simultaneously fitting the trend and the constant at the same time in the model using ordinary least square method of regression (OLS) model.

$$
y_{t}=\Gamma \beta_{t}+\varnothing y_{t-1}+w_{t}
$$

Stationarity properties of the variables were assessed by the Kwiatkowski-Phillips-Schmidt-Shin (KPSS) (1992) test and the augmented Dickey-Fuller (ADF) test, before the Johansen test, the vector error correction models, as well as the VAR test were performed.

\subsection{Data}

Data for the estimation of the association between interest rates and inflation are monthly and quarterly with interest rate proxied by T-Bill rates for 182-day and 91-day for Ghana (between 20072013). Ghana database is the source of the data, with 83 sample.

Table 1 Data Sources of Data, Proxies, and Description

\begin{tabular}{|l|c|c|}
\hline Data Description & Proxy & Source \\
\hline Interest Rate (TBR 182_day) & 182-day T-bill Rate & Bank of Ghana \\
\hline Interest Rate (TBR_91_day) & 91-day T-bill Rate & Bank of Ghana \\
\hline Inflation (INF) & Consumer Price Index (CPI) & Bank of Ghana \\
\hline
\end{tabular}




\section{Results}

\subsection{Descriptive statistics}

Table 2 reports the summary statistics of the model estimated. The central tendencies of the data are measured using the means, and the values show a good fit. The nature of data volatility was assessed using the coefficients of variation (C.V) Higher values indicate more volatility of the data set. The results reveal that the 182-year T-bill rate is more volatile followed by 91 -day T-bill rate and the inflation rate.

Data spread is determined by comparing the values of the maximum and minimum. The inflation variable is more spread with the difference been 515.28 , followed by 182 -day T-bill with the difference been 26.35, and then 91-day T-bill rate.

The dispersion of the data set from their mean values is determined based on the value standard deviation. The higher the deviation and the higher the value of the standard deviation, then the more spread apart of the data set. In the results, inflation is more spread followed by 182-day T-bill rate and the 91-day T-bill rate.

The nature of the distribution of the series (normality) is determined by the values of the coefficients of the skewness. In the results, interest rate proxies are all non-negatively skewed with inflation skewed negatively. The nature of peaks of the data distribution is determined by the values of the coefficient of kurtosis measures. The values for interest rate proxies and inflation in absolute terms are all larger than zero indicating more peaked-topped distribution with all the variables having a peak value less than 3 . The values of the skewness and the kurtosis indicate normally distributed data set.

Table 2 Illustrative Data

\begin{tabular}{|ccccc|}
\hline \multicolumn{5}{c|}{ Using the observations 2007:01 - 2013:11 } \\
\hline Variable & Mean & Median & Minimum & Maximum \\
TBR_182_day & 17.6410 & 13.9000 & 9.8500 & 36.2000 \\
TBR_91_day & 16.9249 & 14.0000 & 9.1300 & 27.8000 \\
INF & 340.4050 & 346.6000 & 24.4200 & 539.7000 \\
Variable & Std. Dev. & C.V. & Skewness & Ex. kurtosis \\
TBR_182_day & 6.8489 & 0.3882 & 0.4732 & -1.0456 \\
TBR_91_day & 6.3046 & 0.3725 & 0.1974 & -1.6712 \\
INF & 111.6280 & 0.3279 & -0.3992 & -0.2929 \\
\hline
\end{tabular}

Author's computation, February 2018

\subsection{Test Results of Stationarity}

The KPSS and ADF models. were used to analyse the stationarity features of the data used. Results are presented in sections 3.2.1 and sections 3.2.2.

\subsubsection{Plots of Time Series}

Figure 1 to Figure 3 indicates time series plots in levels and figure 4 to 6 in the first difference. The figures show that the 182-day T-bill rates, 91-day T-bill rates, and inflation rates are not stationary in levels. On first differenced they became stationary (Figures 4, Figure 5, and Figure 6). The properties of stationarity are subsequently investigated using both the KPSS and ADF tests. The test results are reported in Tables 3 and Table 4. 


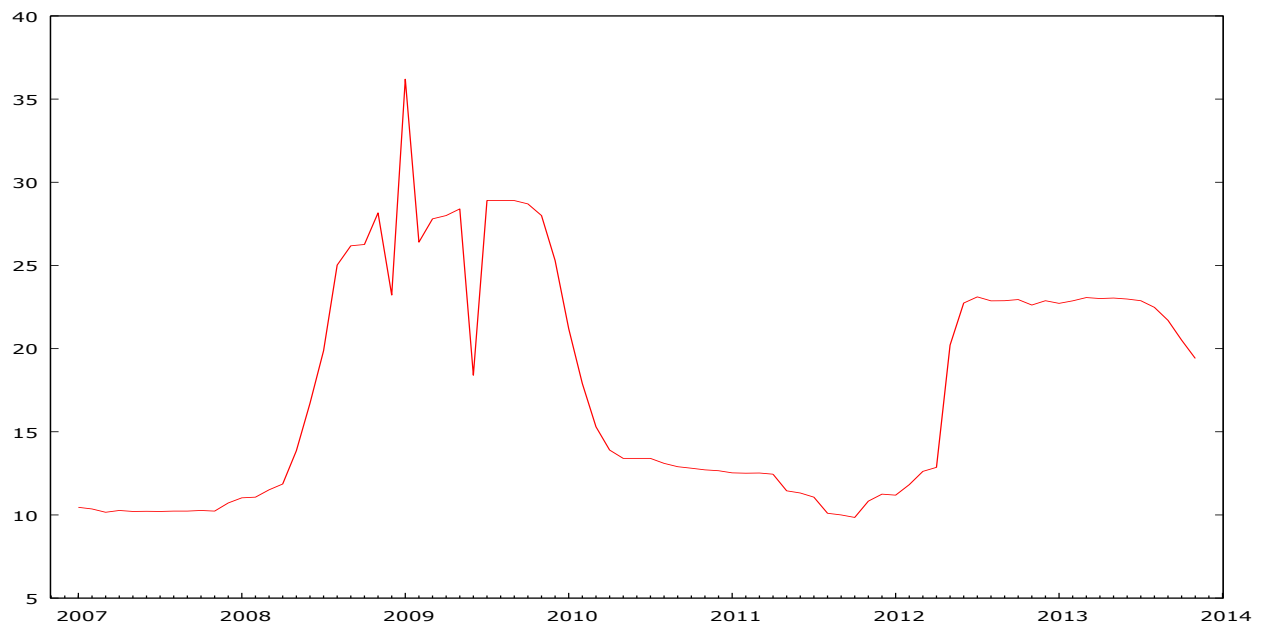

Figure 1 Plots of 182-day T-bill rates (levels)

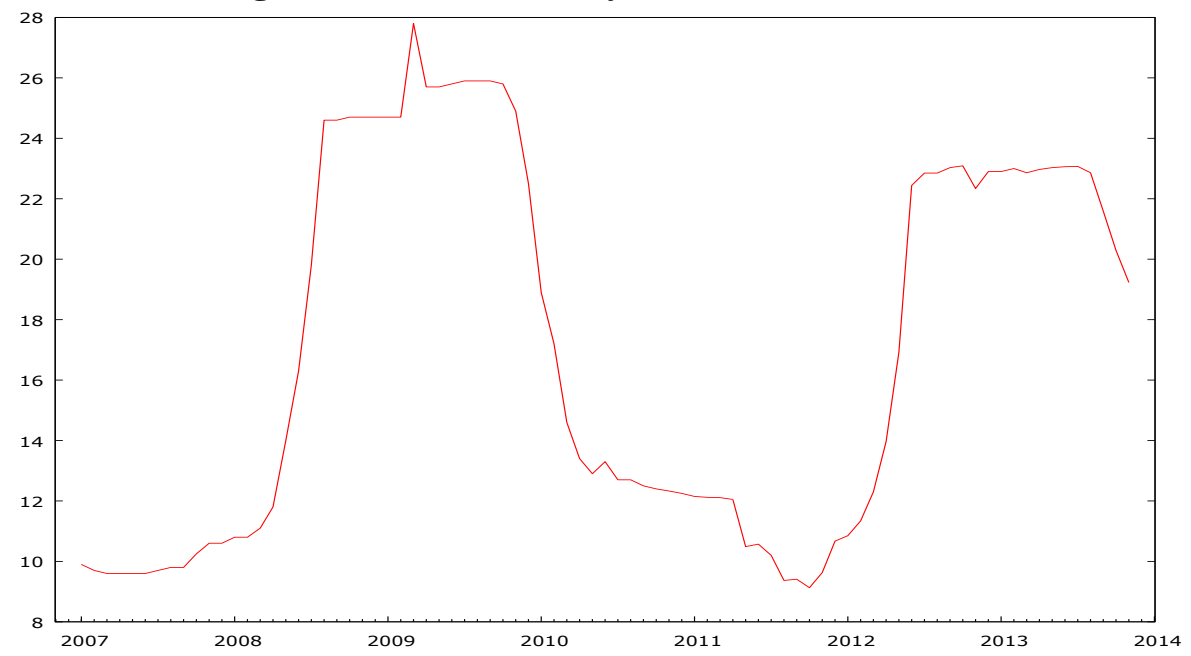

Figure 2 Plots of 91-day T-bill rates (levels)

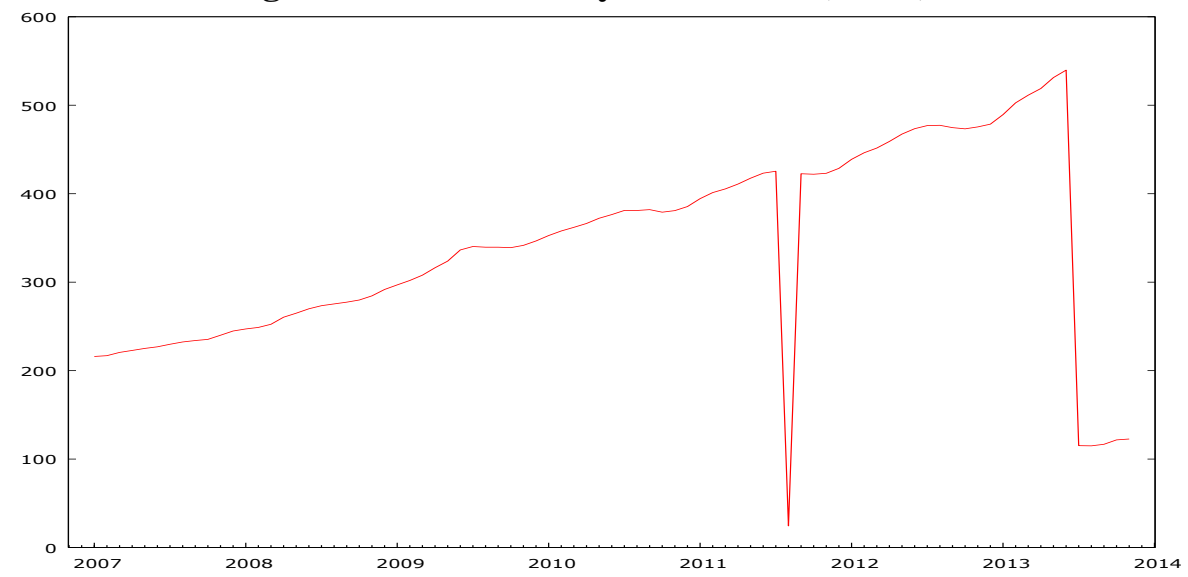

Figure 3 Plots of Inflation rates (levels) 


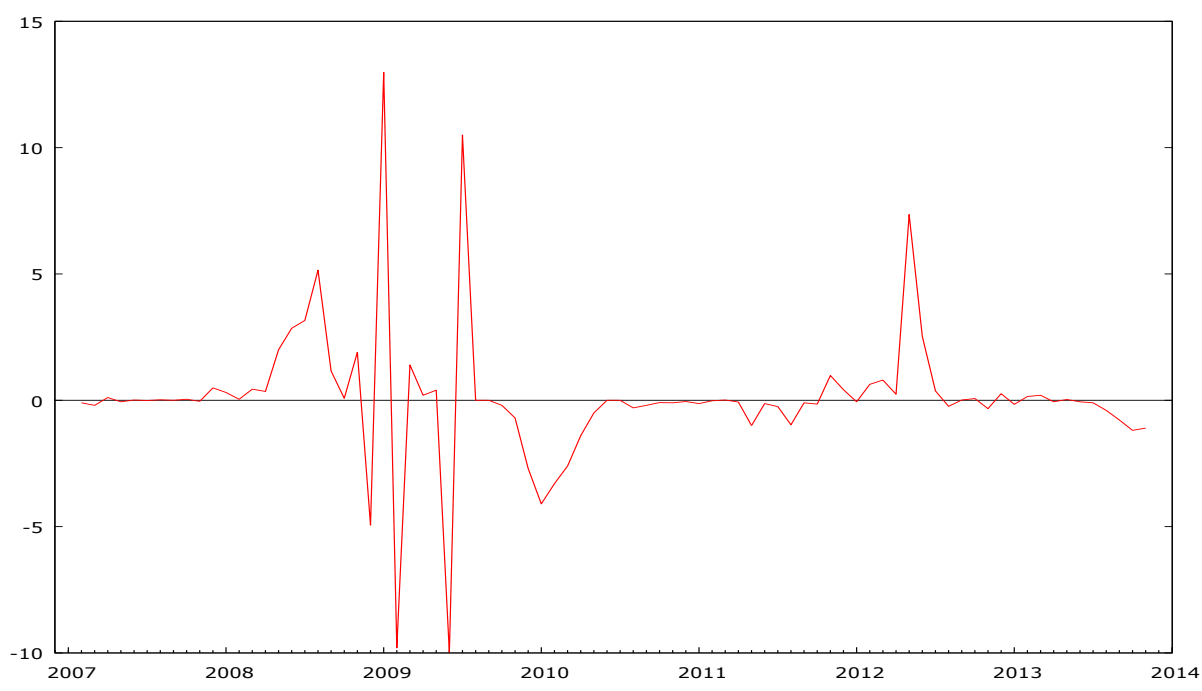

Figure 4 Plots of 182-day T-bill rates $\left(1^{\text {st }}\right.$ difference)

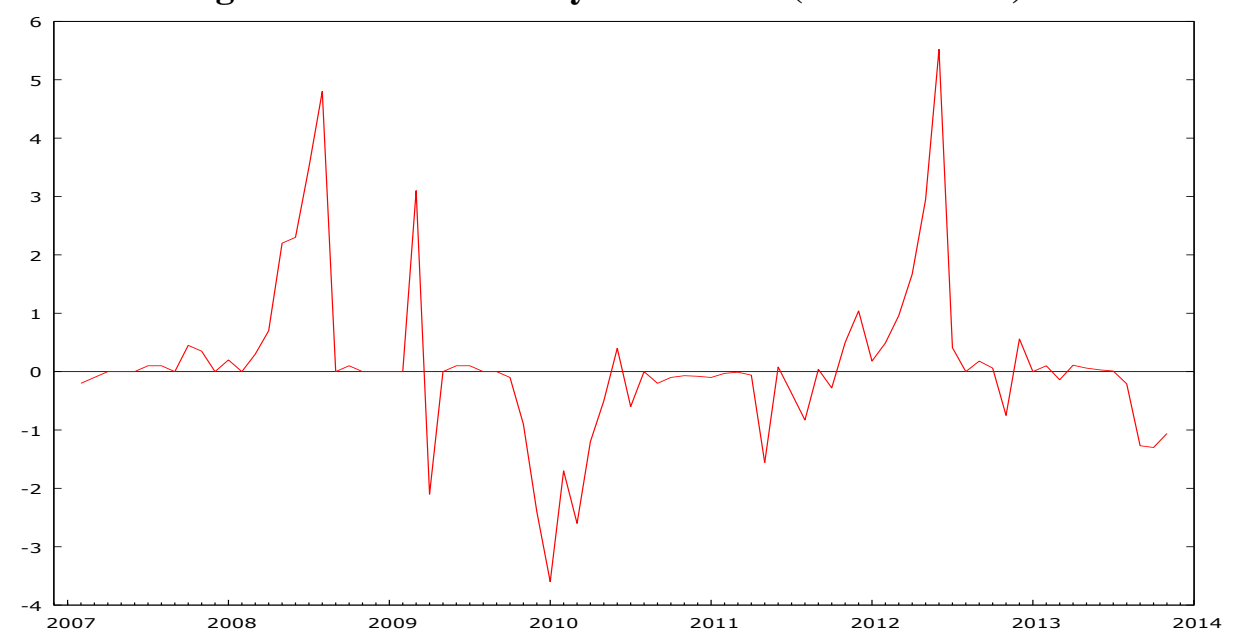

Figure 5 Plots of 91-day T-bill rates $\left(1^{\text {st }}\right.$ difference)

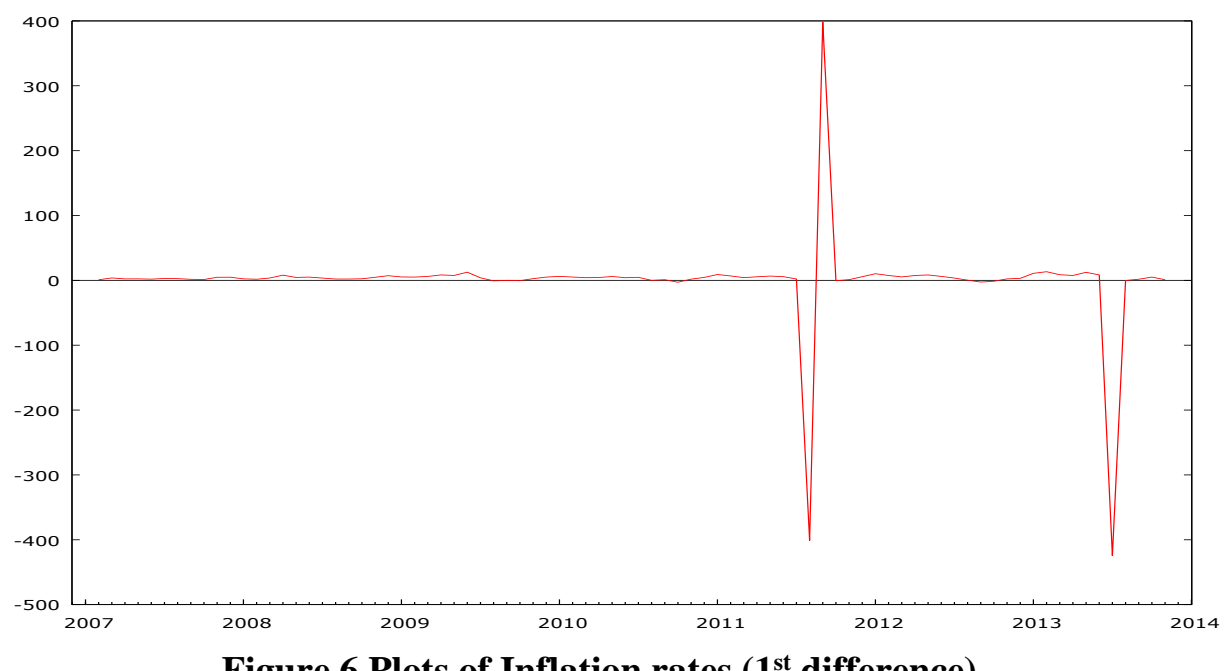

Figure 6 Plots of Inflation rates $\left(1^{\text {st }}\right.$ difference)

\subsection{Stationarity Test Results}

KPSS and the ADF tests results are shown in Table 3 and Table 4. The null assumption for the $\mathrm{ADF}$ test states the series are non-stationary. The ADF test statistic is a non-positive number. If the test statistic is more negative, the null assumption is strongly rejected at various levels of confidence $(10 \%$, $5 \%$, and $1 \%$ ). The results indicate the series (TBR-182-day, TBR-91-day and INF) are unit root in levels 
according to the ADF test. On first differenced they series variables achieved stationarity. This means an external shock to the series is not temporary but permanent.

Table 3 The ADF Unit Root Results including a Time Trend and a Constant

\begin{tabular}{|l|c|c|c|c|}
\hline Variables & T-statistic & P-value & Results & $\begin{array}{c}\text { Max } \\
\text { Lag }\end{array}$ \\
\hline TB182-D-levels & -2.0259 & 0.5865 & Unit root & 12 \\
\hline TB182-D-1 ${ }^{\text {st }}$ diff. & -3.6432 & $0.0263^{* *}$ & Not unit root & 12 \\
\hline TB91D-level & -2.9669 & 0.1416 & Unit root & 12 \\
\hline TB91D-1 ${ }^{\text {st }}$ diff. & -4.7844 & $0.0011^{* * *}$ & Not unit root & 12 \\
\hline INF & -1.8685 & 0.6708 & Unit root & 12 \\
\hline INF-1 ${ }^{\text {st }}$ diff. & -12.5232 & $0.0000^{* * *}$ & Not unit root & 12 \\
\hline Critical values & $-3.15(10 \%)$ & $-3.45(5 \%)$ & $-4.04(1 \%)$ & \\
\hline
\end{tabular}

Source: Author's calculation, February 2018,

The KPSS test null hypothesis states the series are not in levels unit root against the alternative assumption of a unit root in levels. The results (Table 4) based on the KPSS test indicate the series variables are not in levels non-stationary. However, they achieved stationarity on the first difference. Therefore, the null preposition of stationary in levels of the series is accepted. The null assumption of stationary is rejected if the value of the KPSS test statistic is higher than the KPSS critical value. The results in Table 4 indicate that the KPSS determined values are lower than the KPSS critical values at $1 \%$ and $5 \%$ levels of significance. The null assumption of stationarity is accepted and not rejected. The data set is order zero integrated I (0).

Table 4 Results of the KPSS Stationarity Test including a Trend and a Constant

\begin{tabular}{|c|c|c|c|}
\hline Variables & Value of KPSS Test & Results & $\begin{array}{c}\text { Maximum } \\
\text { Lag }\end{array}$ \\
\hline TB182-D-levels & 0.0883 & No unit root (Stationary) & 12 \\
\hline TB182-D-1 st diff. & 0.0786 & No unit root (Stationary) & 12 \\
\hline TB91D-level & 0.0883 & No unit root (Stationary) & 12 \\
\hline TB91D-1st diff. & 0.0783 & No unit root (Stationary) & 12 \\
\hline INF & 0.1297 & No unit root (Stationary) & 12 \\
\hline INF-1st diff. & 0.1103 & No unit root (Stationary) & 12 \\
\hline & \multicolumn{3}{|c|}{$10 \% \quad 5 \% \quad 1 \%$} \\
\hline
\end{tabular}

Source: Author's calculation, February 2018

\section{3 Johansen Cointegration Test Result}

\subsubsection{Johansen Cointegration test result for Interest Rate (proxied by 182-day T-bill Rates) and} Inflation

The Johansen test results for the assessment of the stable long-run association between the interest rates (proxied by 182-day T-bill rates) and inflation are shown in Table 5. The results reveal a long-term significant association between the series. The maximum Eigenvalue test and the trace test did not fail the test of stability. At least there is one cointegration rank between interest (proxied by 182-day T-bill rate) and inflation at the significance level of 5\%.

The assessment of the short-run link between interest (182-day T-bill rate) rate and inflation using the error correction model shows that there is still not equilibrium in the short-term because the value of the error correction term (ECM-1=-0.1777; $\mathrm{p}=0.0044)$ is at $1 \%$ level significant. The value has the expected negative a priori theoretical sign. The value indicates that almost $18 \%$ of errors generated in the past period is corrected in the estimated model in the current period. The value indicates a slow correction in moving from the short-term to the long-term. The adjusted R-squared (0.1674) value indicates that in the estimated model, in the short-run about $167 \%$ of the changes in the model is accounted for by inflation and that the model is not well-fitted. 
Table 5 Test Results for the Long-run Analysis

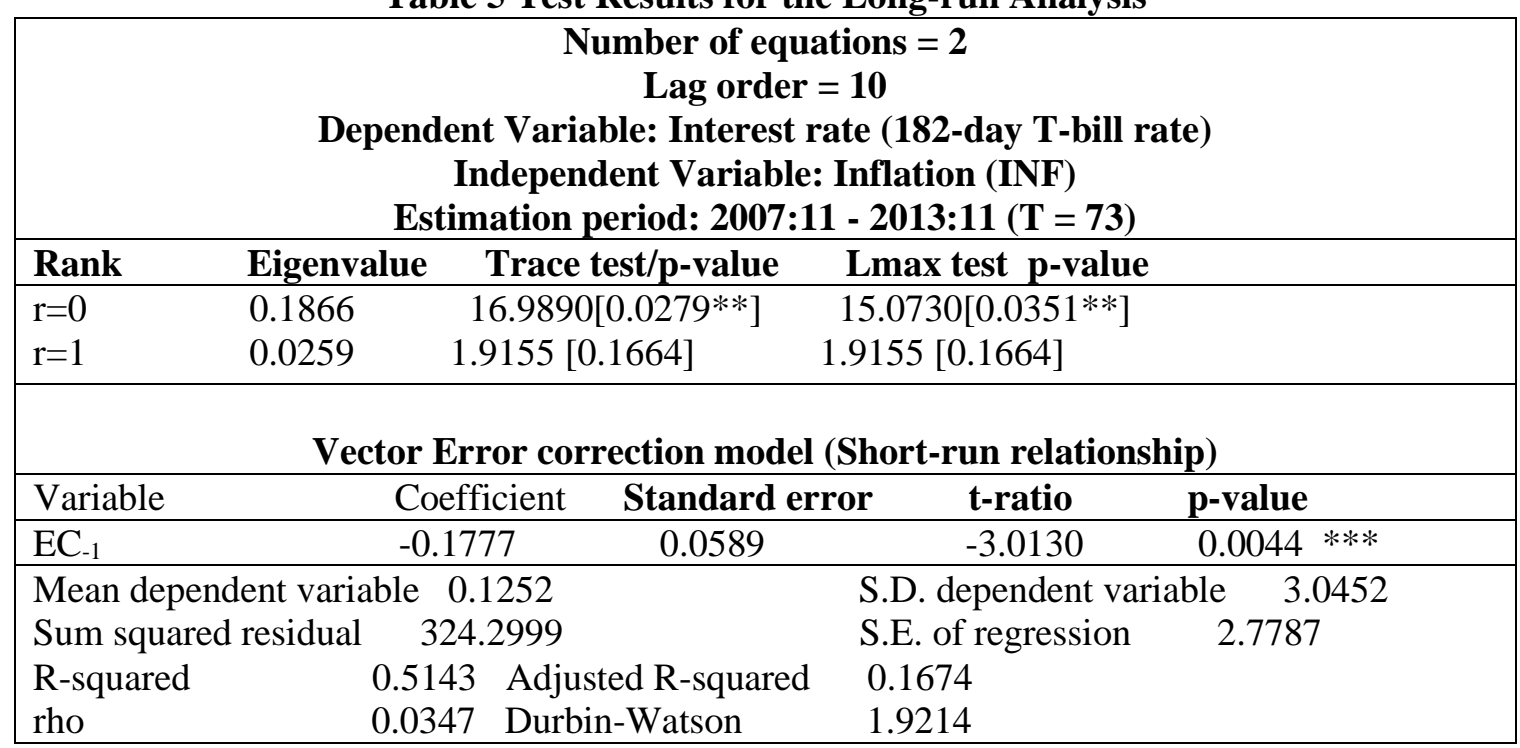

Source: Author's Estimation, February 2018. Note ** and *** show significance at 5\% and $1 \%$ levels of significance respectively

\subsubsection{Vector Autoregression Test Results (VAR) for Interest Rates and Interest Rates (proxied by 182-day Treasury Bill Rates)}

The VAR test results are depicted in Table 6 The empirical results indicate that 182-day treasury bill rate lag 1 affect the current values of the 182-day Treasury bill rates at $1 \%$ level of significance, whereas 182-day treasury bill rate lag 2 and lag 4 also affect current values of 182-day Treasury bill rates at 10\% levels of significance. The lag 3 of the 182-day Treasury bill rates and all the lags (1 to 4 ) of inflation variable do not significantly influence the current values of the 182-day treasury bill rates. The tread variable (time) is not significant, whereas the constant in the model is significant.

Whereas all the lags ( 1 to 4 ) of the 182-day treasury bill rate significantly influence current values of the 182-day treasury bill rate, all the inflation lags (1 to 4$)$ do not affect the current values of the interest (proxied by 182-day treasury bill rate). The value of the Unadjusted $\mathrm{R}^{2}(0.8519)$ show the model is best fitted and it indicates that the changes in the estimated model are explained about $85.2 \%$ by inflation.

The results of the F-tests of zero restrictions $[\mathrm{F}(4,69)=80.6870, \mathrm{p}=0.0000]$ indicate that all lags of the interest rates (proxied by the 182-day Treasury bill) are significant in influencing the current values of the interest rates at $1 \%$ Also, the F-tests of zero restrictions $[F(4,69)=1.1666, p=0.3332]$ indicate that all lags of the inflation variable are not significant in influencing the current values of the interest rates (proxied by 182-day treasury bill rates).

Finally, all the lags of the variables are not significant in influencing the current values of interest rates (proxied by 182-day treasury bill rates). The value of the Unadjusted $\mathrm{R}^{2}(0.9704)$ show the model is best fitted and it indicates that the variations in the model estimated are accounted for by inflation about $97 \%$.

Table 6 VAR Test Results

VAR System lag order 4

OLS estimates, Observations 2008:2-2027:4 $(\mathrm{T}=79)$

Log-likelihood $=-638.53604$

Determinants of covariance matrix $=3594.92$

$$
\begin{aligned}
\mathrm{AIC} & =16.6718 \\
\mathrm{BIC} & =17.2717 \\
\mathrm{HQC} & =16.9121
\end{aligned}
$$

Portmanteau test: $\mathrm{LB}(19)=29.8712(\mathrm{df}=60, \mathrm{p}$-value 0.9996)

Equation 1: TBR_182_day

Heteroskedasticity-robust standard errors, variant $\mathrm{HC} 1$ 


\begin{tabular}{|lcccc|}
\hline Variable & Coefficient & Std. Error & $t$-statistic & $p$-value \\
constant & 1.3250 & 0.6401 & 2.0702 & $0.0422^{* *}$ \\
TBR_182_day_1 & 0.6441 & 0.2228 & 2.8906 & $0.0051^{* * *}$ \\
TBR_182_day_2 & 0.4839 & 0.2540 & 1.9051 & $0.0609^{*}$ \\
TBR_182_day_3 & -0.0437 & 0.1154 & -0.3784 & 0.7063 \\
TBR_182_day_4 & -0.1780 & 0.0976 & -1.8236 & $0.0726^{*}$ \\
INF_1 & 0.0017 & 0.0012 & 1.4433 & 0.1535 \\
INF_2 & 0.0013 & 0.0009 & 1.5047 & 0.1369 \\
INF_3 & -0.0004 & 0.0007 & -0.6054 & 0.5469 \\
INF_4 & -0.0005 & 0.0010 & -0.4307 & 0.6681 \\
time & -0.0065 & 0.0108 & -0.6045 & 0.5475 \\
\hline
\end{tabular}

Mean of dependent variable $=18.0120$

The standard deviation of dependent variable. $=6.8132$

Sum of squared residuals $=535.9530$

Standard error of residuals $=2.7870$

Unadjusted $\mathrm{R}^{2}=0.8519$

F-statistic $(9,69)=134.584(\mathrm{p}$-value $<0.0000)$

Durbin-Watson statistic $=2.1034$

First-order autocorrelation coefficient. $=-0.0524$

F-tests of zero restrictions:

All lags of TBR_182_day $\mathrm{F}(4,69)=80.687$, p-value $0.0000 * * *$

All lags of INF $\quad F(4,69)=1.1666$, p-value 0.3332

All vars, lag $4 \quad F(2,69)=1.7305$, p-value 0.1848

Source: Author's Estimation, August 2018. Note * and $* * *$ show significance at $10 \%$ and $1 \%$ levels of significance respectively

\subsubsection{Diagnostic Test Results}

Table 7 depicts the results of the test of the diagnostic of the VAR model to assess the coefficients of estimated parameter reliability. The tests are the autoregressive conditional heteroskedasticity $(\mathrm{ARCH})$ test which deals with the effect of serial correlation of the heteroskedasticity. The effect of no ARCH is the null assumption against the alternative preposition that ARCH effect is present. The other test is the test for multivariate normality of residuals on the null preposition that the residuals are not skewed against the alternative assumption that they are skewed in distribution. The last test is the autocorrelation test which is on the null hypothesis of no autocorrelation. The model estimated did not pass the ARCH test, test for multivariate normality of residuals, but passed the test of autocorrelation.

Table 7 Diagnostic Test Results of VAR

A. Test for ARCH of order 4

Null assumption: ARCH condition is absent

Value of Test statistic: $\mathrm{TR}=8.3516$

Probability $(\mathrm{P}$-value $)$ value $=\mathrm{P}($ Chi-square $(4)>8.3516)=0.0795$

Decision: There is ARCH effect

B. Residual correlation matrix, C (2 x 2)

Null hypothesis: Test for multivariate normality of residuals. The residuals are normally distributed

Doornik-Hansen Chi-square $(4)=130.138$, with p-value $=0.000 * * *$

Decision: The residuals are not normally distributed.

C. LM Test for Autocorrelation up to order 4 
Null assumption: autocorrelation is absent

Value of Test statistic LMF $=0.5128$

Probability $(\mathrm{P}$-value $)$ value $=\mathrm{P}(\mathrm{F}(4,61)>0.5128)=0.7265$

Decision: There is no autocorrelation

Source: Author's computation, February 2018. Note *** and ** show significance at $1 \%$ and $5 \%$ levels of significance respectively

\subsubsection{Johansen Cointegration test result for Interest Rate (proxied by 91-day T-bill Rates) and Inflation Rates}

The results on the long-run link between the interest rate (proxied by 91-day T-bill rates) and inflation are shown in Table 8. The test results depict a significant long-run association between the series under analysis. The results of the maximum Eigenvalue test and the trace test did not fail the test of stability indicating at least one cointegration rank between interest (proxied by 91-day T-bill rates) and inflation at $10 \%$ level of significance.

Results for the short-run dynamics test reveals that there is no equilibrium in moving to the short-term since the error correction term (ECM-1=-0.0816; $\mathrm{p}=0.0087)$ is at $1 \%$ level stable. The value of the error correction model has the negative expected a priori theoretical sign. The value indicates that almost $8 \%$ of errors created in the past period is corrected in the present time in the model modelled. The value indicates a very slow correction in moving to the long-term from the short-term. The value of the adjusted R-squared (0.3327) reveals that in the short-term the model estimated about $33.3 \%$ of the variations in the model estimated is accounted for by inflation and this does not show a well-fitted model.

Table 8 Long-term association between the Interest rates (91-day T-bill rate) and Inflation

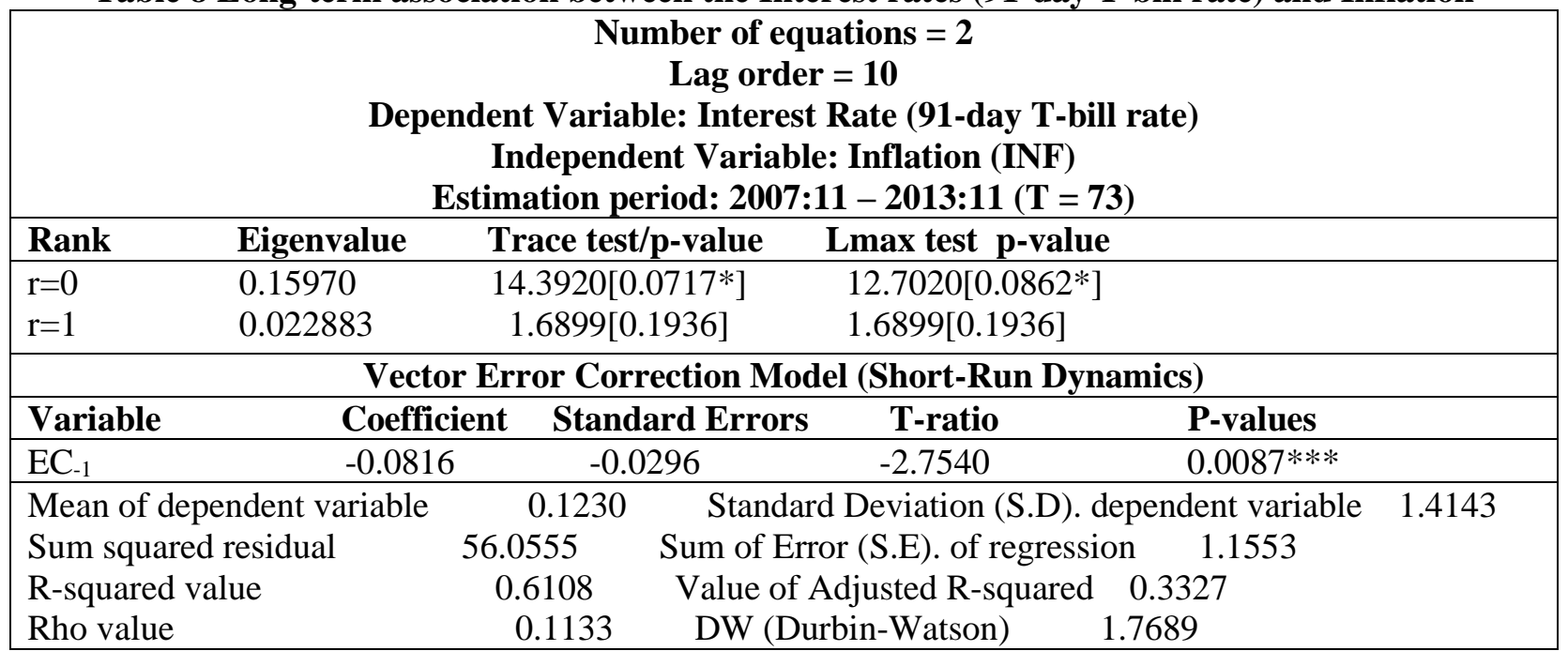

Source: Author's Estimation, February 2018. Note* and *** show significance at $10 \%$ and $1 \%$ levels of significance respectively

\subsubsection{The Vector Autoregression Model Test Results (VAR) for Inflation and Interest Rates (Proxied by 91-day Treasury Bill Rates)}

The VAR test results are shown in Table 9 with the dependent variable been interest rates (proxied by 91-day treasury bill rates) and the independent variable been inflation variable. The empirical results indicate that interest rate lag 1 (proxied by 91-day treasury bill rate lag 1) affect the current values of the interest rates (proxied by 91-day treasury bill rates) at $1 \%$ level of significance negatively, whereas interest rates lag 2, 3, and 4 (proxied by 91-day treasury bill rate lags $2,3, \& 4$ ) do not significantly influence current values of interest rates (proxied by 91 -day treasury bill rates).

The lag 2 and lag 4 of the inflation variable do significantly influence the current values of the interest rate (proxied by 91-day treasury bill rates) positively and negatively respectively. The inflation variable lag 3 at 10\% significant level influence current values of interest rates (proxied by 91-day 
treasury bill rates) negatively. The tread variable (time) is not significant, whereas the constant in the model is significant at $5 \%$ level.

The results of the F-tests of zero restrictions $[\mathrm{F}(4,69)=587.07, \mathrm{p}=0.0000]$ indicate that all lags of the interest rates (proxied by 91-day treasury bill rates) are significant in influencing the current values of the interest rates (proxied by treasury bill rates) at $1 \%$ Also, the F-tests of zero restrictions $[F(4,69)=16.055, p=0.0000]$ indicate that all lags of the inflation variable are significant in influencing the current values of the interest rates (proxied by 91-day treasury bill rates) at $1 \%$.

Lastly, at the $1 \%$ level of significance, all the lags of the variables are significant in influencing the current values of interest rates (proxied by 91-day treasury bill rates). The value of the Unadjusted $\mathrm{R}^{2}(0.9704)$ show the model is best fitted and it indicates that the changes in the model estimated are accounted for by inflation at about $97 \%$.

Table 9 VAR Results

VAR system, lag order 4

OLS estimates, observations 2008:2-2027:4 $(\mathrm{T}=79)$

Log-likelihood $=-567.29337$

Determinant of covariance matrix $=5920.0694$

$$
\begin{aligned}
\mathrm{AIC} & =14.8682 \\
\mathrm{BIC} & =15.4680 \\
\mathrm{HQC} & =15.1085
\end{aligned}
$$

Portmanteau test: $\mathrm{LB}(19)=52.6973(\mathrm{df}=60, \mathrm{p}$-value 0.7370)

Equation 1: TBR_91_day

Heteroskedasticity-robust standard errors, variant $\mathrm{HC} 1$

\begin{tabular}{|lcccc|}
\hline \multicolumn{1}{c}{ Variable } & Coefficient & Std. Error & t-statistic & $p$-value \\
constant & 0.8230 & 0.3536 & 2.3273 & $0.0229^{* *}$ \\
TBR_91_day_1 & 1.3835 & 0.2234 & 6.1936 & $<0.0000^{* * *}$ \\
TBR_91_day_2 & -0.2555 & 0.2665 & -0.9588 & 0.3410 \\
TBR_91_day_3 & -0.1117 & 0.1259 & -0.8873 & 0.3780 \\
TBR_91_day_4 & -0.0653 & 0.0705 & -0.9264 & 0.3575 \\
INF_1 & 0.0004 & 0.0005 & 0.7805 & 0.4378 \\
INF_2 & 0.0018 & 0.0003 & 5.6075 & $<0.0000^{* * *}$ \\
INF_3 & -0.0007 & 0.0004 & -1.7135 & $0.0911^{*}$ \\
INF_4 & -0.0014 & 0.0005 & -3.1769 & $0.0022^{* * *}$ \\
time & 0.0013 & 0.0042 & 0.3010 & 0.7643 \\
\hline MFe & & & &
\end{tabular}

Mean of dependent variable $=17.2908$

The standard deviation of dependent. variable. $=6.2428$

Sum of squared residuals $=89.9624$

Standard error of residuals $=1.1418$

Unadjusted $\mathrm{R}^{2}=0.9704$

F-statistic $(9,69)=653.446(\mathrm{p}$-value $<0.0000)$

Durbin-Watson statistic $=1.9950$

First-order autocorrelation coefficient. $=0.0016$

F-tests of zero restrictions:

All lags of TBR_91_day $\mathrm{F}(4,69)=587.07$, p-value $0.0000^{* * *}$

All lags of INF $\quad \mathrm{F}(4,69)=16.055$, p-value $0.0000^{* * *}$

All vars, lag $4 \quad \mathrm{~F}(2,69)=5.9107, \mathrm{p}$-value $0.0043^{* * *}$

Source: Author's computation, August 2018. Note *;** and *** show significance at 10\%; $5 \%$, and $1 \%$ levels of significance respectively 


\subsubsection{Diagnostic Test Results}

Table 10 shows the results of the test of the diagnostic of the VAR model to assess the reliability of the estimated parameter coefficients. These tests are the autoregressive conditional heteroskedasticity $(\mathrm{ARCH})$; the test for multivariate normality of residuals as well as the test of autocorrelation. The model estimated failed the ARCH test, test for multivariate normality of residuals, but passed the test of autocorrelation.

Table 10 VAR Diagnostic Test Results

Null assumption: ARCH effect is absent

Test statistic: $\mathrm{TR}=21.4346$

$\mathrm{P}$-value $=\mathrm{P}($ Chi-square $(4)>21.4346)=0.0003^{* * *}$

Decision: There is ARCH effect

B. Residual correlation matrix, C $(2 \times 2)$

Null assumption: Test for multivariate normality of residuals. The residuals are normally distributed

Doornik-Hansen Chi-square $(4)=115.425$, with p-value $=0.000 * * *$

Decision: The residuals are not normally distributed.

C. LM Test for Autocorrelation up to order 4

Null assumption: autocorrelation is absent

Test statistic: $\mathrm{LMF}=0.1493$

$\mathrm{P}$-value $=\mathrm{P}(\mathrm{F}(4,58)>0.1493)=0.9626$

Decision: There is no autocorrelation

Source: Author's computation, August 2018. Note *** shows significance at $1 \%$ level

\subsubsection{Granger Predictability Test Results}

Granger predictability test is on the null assumptions that inflation does not Granger cause interest rates, and interest rate does not Granger cause inflation against the alternative assumptions that inflation Granger causes interest rate, and interest rates Granger cause inflation. The results are shown in Table 11 and Table 12. The results show that there is no significant Granger predictive causality direction (either unidirectional and bidirectional) between inflation and interest rates (proxied by both the 91-day and 182-days). This means there is a neutral causality between the variables in the model estimated.

Table 11. Granger CausalityTest Results

\begin{tabular}{|l|c|c|c|}
\hline Variables & $\begin{array}{c}\text { Chi-square } \\
\text { value }\end{array}$ & P-values & Decision \\
\hline LNINF does not predict LNTB182 & 81 & 0.7600 & Accept $\mathrm{H}_{\mathrm{O}}$ \\
LNTB182 does not predict LNINF & & 0.9993 & Accept $\mathrm{H}_{\mathrm{O}}$ \\
\hline
\end{tabular}

Source: Author's Estimation, August 2018

Table 12. Predictive Test Results of Granger

\begin{tabular}{|l|c|c|c|}
\hline Variables & $\begin{array}{c}\text { Chi-square } \\
\text { value }\end{array}$ & P-values & Decision \\
\hline LNINF does not predict LNTB91 & 80 & 0.6566 & Accept $\mathrm{H}_{\mathrm{O}}$ \\
LNTB91 does not predict LNINF & & 0.9513 & Accept $\mathrm{H}_{\mathrm{O}}$ \\
\hline
\end{tabular}

Source: Author's Estimation, August 2018. 


\subsection{Discussions}

The empirical test results of the KPSS test and the ADF test, for the investigation of the stationarity features of the series variables, indicate that the series are in levels are unit root and not when first differenced for the ADF results. The Johansen test results for the assessment of long-run link and then the error correction model for the short run nexus show that the variables are cointegrated with a stable long-run link.

The results to a very great degree indicate that inflation has both short-run and association with interest rates. The findings are in line with past studies such as Panopoulou (2005), Gül and Ekinci (2006), Herwartz and Reimers (2006), Westerlund (2006), Ling et al. (2008), Sathye, Sharma and Liu (2009), Mahdi and Masood (2011), Ayub et al. (2014), Ida \& Luguterah (2014), and Jaradat and AIHhosban (2014) works that reported of a stable association in a similar study. The findings of a significant long-term link between interest rates and inflation in the current empirical study support the Fisher effect (1930).

Concerning the direction of causality, the findings of the Granger predictability test indicate no significant causality between inflation and interest rates (proxied by both 91-day T-Bill Rates and 182day T-Bill Rates). The findings are not in support of that of the study of Logubayom and Luguterah (2014) study for Ghana who reported of a significant unidirectional Granger causality between interest rates (182-day T-Bill Rates) and inflation with causality running to interest rates from inflation. However, the findings are in agreement with the works of Logubayom and Luguterah (2014) for Ghana in the direction of causality between inflation and interest rates (proxied by 91-day treasury bill rates). The findings of their study and that of the current study reveal no causality between interest rates and inflation. The current study findings are not consistent with that of Incekara et. al. (2015) for Turkey with predictive direction from inflation to interest rates; Köksel and Destek (2015) for Turkey with predictive direction from inflation to interest rates and Doğan et al. (2016) for Turkey running to interest rates from inflation. Karahan and Y1lgör (2017) in a similar study for Turkey reported a significant link between inflation and interest rates with Granger causality running to interest rates from inflation.

Other studies have also reported significant bidirectional causality which is contrary to the findings of the current study for countries such as Iran and Nigeria. For example, in Mahdi and Masood (2011) study indicated bidirectional causality for inflation-interest rates link, and in Nigeria, Amaefula (2016) reported of causality running to inflation from interest rates.

\section{Conclusion}

The main purpose of the research is to assess the association between inflation on interest rates for Ghana for the period 2007 to 2013 to test for the presence of Fisher effect. The purpose has been attained using the KPSS and ADF test for assessment of stationarity properties. The Johansen (Trace test and Lmax test) test, was performed to investigate the presence of a stable long-term link in the series in the cointegration test.

The findings indicate a steady long-term nexus between the series variables. The presence or otherwise of a short-run link was assessed using the vector error correction model. The findings indicated a stable short-run association between the variables. For policymakers to ensure a stable economy for sustainable growth the findings of the current study should be taken into consideration since there is stable both short-term and a long-term link between inflation and the interest rates.

The findings of the analysis of the dynamic link between interest rates and inflation show that the dynamic link between inflation (lag 1 to lag 4 ) and interest rates (proxied by 182-day T-Bill Rates) is not significant. This means inflation is not a policy tool to influence interest rates. However, the past values of interest rates significantly influence the current values of interest rates. This also means that the previous values of interest rates are appropriate in explaining the current values of interest rates.

In Taking the interest rates (proxied by 91-day T-Bill Rates), into account, there is a significant link between inflation (lag 2, lag 3, and lag 4) and current values of interest rates, whereas only the lag 1 values of interest rates significantly affect the current value of interest rates.

The implication of the insignificant findings of the Granger causality between inflation and interest rates (proxied by 182-day T-Bill Rates and 91-day T-Bill rates) is that inflation variable is not reliable as a policy tool to predict future values of interest rates for the period under discussion. That is, price stability is not essential in managing interest rates. 


\section{Limitation and study forward}

The Johansen test is considered as an improved model for testing cointegration link among variables than other models such as Stock and Watson as well as Engle-Granger test since it does not determine the dependent variable in the estimated model and it also can detect multiple cointegrating vectors (Wassell \& Saunders, 2008). However, according to researchers (Gonzalo \& Lee, 1997) in most cases, the Engle-Granger test is more robust than the Johansen model. Hence, future studies should consider both tests in a comparative study to find out if these findings could be supported. Later research accounting for structural breaks are worth doing to find out if the present conclusions could collaborate.

\section{References}

Amaefula, C. G. (2016). Long-run relationship between interest rate and inflation: evidence from Nigeria. Journal of Economics and Finance, 7 (3), 24-28

Ayub, G., Rehman, N. U., Iqbal, M., Zaman, Q., \& Atif M. (2014). Relationship between inflation and interest rate: evidence from Pakistan. Research Journal of Recent Sciences, 3(4), 51-55.

Banerjee, A., Dolado, J. J., Galbraith, J. W., \& Hendry, D. F. (1993). Co-integration, error-correction, and the econometric analysis of non-stationary data, Oxford University Press, Oxford.

Benhabib, J., Schmitt-Grohé, S., Uribe, M., (2002). Chaotic interest-rate rules. The American Economic Review, 92 (2), 72-78.

Berument, H., \& Jelassi, M. (2002). The fisher hypothesis: a multi-country analysis. Applied Economics, 34 (13), 1645-1655.

Dickey, D., Wayne, A. F. (1979). Distribution of the Estimators for Autoregressive Time Series with a Root". Journal of the American Statistical Association, 74, 427-431.

Doğan, B., Eroğlu Ö. \& Değer, O. (2016). The causal relationship between inflation and interest rates: the case of Turkey, Çankırı Karatekin University. Journal of the Faculty of Economics and Administrative Sciences, 6(1), 405-425.

Fahmy, Y., \& Kandil, M. (2003). The fisher effect: new evidence and implications. International Review of Economics \& Finance, 12(4), 451-465.

Fama, E. (1975). Short-term interest rates as predictors of inflation. The American Economic Review, 65(3), 269-282.

Fama, E., \& Schwert, G. (1977). Asset returns and inflation. Journal of Financial Economics, 5(2), $115-146$.

Fisher, I. (1930). The theory of interest. New York, USA, Macmillan.

Gonzalo, J. \& Lee, T. (1998). "Pitfalls in testing for long-run relationships. Journal of Econometrics, 86(1), 129-154.

Gul, E., Ekinci, A. (2006). The causal relationship between nominal interest rates and inflation: The case of turkey. Scientific Journal of Administrative Development, 4(21), 54-69.

Herwartz, H., Reimers, H. (2006). Modelling the fisher hypothesis: worldwide evidence. Economics Working Papers, (4).

Ida, L. A., \& Luguterah, A. (2014). Modelling the dynamic relationships between treasury bills, inflation and exchange rates in Ghana. American Journal of Economics, 4(5), 200-212.

Incekara, A., Demez, S.\& Ustaoğlu, M. (2012). The validity of the fisher effect for Turkish economy: cointegration analysis. Procedia-Social and Behavioral Sciences, 58, 396-405.

Jaradat, M A., \& AI-Hhosban, A. S. (2014). Relationship and causality between interest rate and inflation rate case of Jordan. Interdisciplinary Journal of Contemporary Research in Business, 6(4), 54-65.

Johansen, S. (1988). Statistical analysis of cointegration vectors. Journal of Economic Dynamics and Control, 12(2-3), 231-254.

Karahan, Ö., \& Y1lgör, M. (2017). The causal relationship between inflation and interest rate in Turkey. J. Asian Dev. Stud, 6(2), 16-21. 
Köksel, B., \& Destek, M. A. (2015). Testing of fisher hypothesis in Turkish Economy: an empirical analysis upon 2001-2014 Period. The Journal of International Social Research, 8(41), 12471253.

Kwiatkowski, D., Phillips, P. C. B., Schmidt, P., \& Shin, Y. (1992). Testing the null hypothesis of stationarity against the alternative of a unit root: how sure are we that economic time series have a unit root? Journal of Econometrics, 54(1-3), 159-178.

Ling, T., Liew, V., Wafa, S., \& Wafa, S. (2010). Does fisher hypothesis hold for the East Asian economies an application of panel unit root tests. Comparative Economic Studies, 52(2), 273285.

Logubayom, A. I., \& Luguterah, A. (2014). Modelling the dynamic relationships between treasury bills, inflation and exchange rates in Ghana. American Journal of Economics, 4(5), 200-212.

Mahdi, S., \& Masood, S. (2011). The long-run relationship between interest rates and inflation in Iran: Revisiting Fisher's hypothesis. Journal of Economics and International Finance, 3(14), 705-712.

Panopoulou, E. A. (2005). Resolution of the fisher effect puzzle: a comparison of estimators. IIIS Discussion Paper, 67, 2005. Available online https://ssrn.com/abstract=680401

Sathye, M., Sharma, D., \& Liu, S. (2009). The fisher effect in an emerging economy: The case of India. International Business Research, 1(2), 99-104.

Summers L. H (1983). The nonadjustment of nominal interest rates: a study of the Fisher effect. In: Tobin J (ed) Macroeconomics, prices and quantities. Blackwell, Oxford, 201-241

Wassell, C. \& Saunders, P. (2008). Time-series evidence on social security and private saving: The issue Revisited.

Westerlund, J. (2008) Panel cointegration tests of the Fisher effect. J. Appl. Economics., 23(2), 193-233

Wilcox, J. (1983). Why real interest rates were so low in the 1970s? The American Economic Review, 73(1), 44-53. 